\title{
ISOLATION OF Helicobacter pylori IN GASTRIC MUCOSA AND SUSCEPTIBILITY TO FIVE ANTIMICROBIAL DRUGS IN SOUTHERN CHILE
}

\section{Laura Otth $^{* 1}$, Myra Wilson ${ }^{1}$, Heriberto Fernández ${ }^{1}$, Carola Otth ${ }^{1}$, Claudio Toledo ${ }^{2}$, Victoria Cárcamo ${ }^{1}$, Paula Rivera $^{1}$, Luis Ruiz ${ }^{1}$}

${ }^{1}$ Institute of Clinical Microbiology, Faculty of Medicine, Universidad Austral de Chile, Valdivia, Chile; ${ }^{2}$ Institute of Medical Specialties, Faculty of Medicine, Universidad Austral de Chile, Valdivia, Chile.

Submitted: August 06, 2010; Approved: November 04, 2010.

\begin{abstract}
Helicobacter pylori colonizes more than $50 \%$ of the world population thus, it is considered an important cause of gastric cancer.

The aim of this study was to determine the isolation frequency of $H$. pylori in Southern Chile from patients with symptomatology compatible with gastritis or gastric ulcer and to correlate these findings with demographic parameters of infected patients and the susceptibility profiles of the isolated strains to the antimicrobial drugs used in the eradication treatments.

A total of 240 patients were enrolled in the study. Each gastric biopsy was homogenized and seeded onto blood agar plates containing a selective antibiotics mixture (DENT supplement). Plates were incubated at $37^{\circ} \mathrm{C}$ in a microaerophilic environment for five days.

The susceptibility profiles to amoxicillin, ciprofloxacin, clarithromycin, tetracycline and metronidazole were determined using the E-test method.

H. pylori was isolated from 99 patients $(41.3 \%)$ with slightly higher frequency in female (42\% positive cultures) than male ( $40.2 \%$ positive cultures).

With regard to age and educational level, the highest isolation frequencies were obtained in patients between 21-30 (55\%) and 41-50 (52.6\%) years old, and patients with secondary (43.9\%) and university $(46.2 \%)$ educational levels.

Nineteen $(21.6 \%)$ strains showed resistance to at least one antimicrobial drug. Tetracycline was the most active antimicrobial in vitro, whereas metronidazole was the less active. One strain $(5.3 \%)$ showed resistance to amoxicillin, clarithomycin and metronidazole, simultaneously.
\end{abstract}

Key words: Helicobacter pylori, antimicrobial susceptibility, gastric ulcer.

*Corresponding Author. Mailing address: Institute of Clinical Microbiology, Faculty of Medicine, Universidad Austral de Chile, PO. Box 567, Valdivia, Chile.; Tel.: 56-63-221921 Fax: 5663 293300.; E-mail: lotth@uach.cl 


\section{INTRODUCTION}

Helicobacter pylori is a motile, curved, Gram negative rod isolated for the first time in 1982 by Warren and Marshall (30). It has been recognized as the main bacterial agent of chronic gastritis and duodenal ulcer, affecting more than $50 \%$ the world population and almost $70 \%$ of the Latin American population $(8,11,19,20,21,24)$.

Once acquired, $H$. pylori produces a persistent infection with inflammation and polymorphonuclear infiltration of gastric mucosa. Some patients can develop atrophic chronic gastritis, considered as a risk factor for further occurrence of adenocarcinoma and gastric lymphoma (20, 21). For this reason, $H$. pylori has been considered as a Group I cancer biological agent (21)

One of the important aspects to consider is the high resistance levels of $H$. pylori to antimicrobials agents commonly used for treatment of gastric mucosal infections, such as ampicillin, clarithromycin, tetracycline and metronidazole reported in Latin America (5, 20, 27, 29). Like other bacteria, H. pylori can show variable behavior to antimicrobials agents in different geographical areas, depending on the locally used drugs $(17,27)$.

The objectives of this work were to determine (i) the isolation frequency of $H$. pylori in Southern Chile from patients with symptomatology compatible with gastritis or gastric ulcer, (ii) the associated demographic parameters (like gender, age and educational level) and their correlation with the infected patients and (iii) the susceptibility profiles of the isolated strains to antimicrobial drugs used in the eradication treatment.

\section{MATERIAL AND METHODS}

A total of 240 patients with a male-to-female ratio of 0.73 (102 males and 138 females), ranging from 11 to 86 years old (mean age, $54.5+/-15.7$ years old) with dyspeptic symptoms from the Valdivia County Hospital in Southern Chile (39 $47^{\prime}$
Southern latitude, $73^{\circ} 15^{\prime}$ Western latitude), were included in this study. All subjects, or their parents, provided written informed consent. Gastric biopsies from the antral region were obtained through esophagogastroduodenoscopy from each patient.

Patients receiving treatment with antimicrobial, anticoagulant or proton pump inhibitory drugs were excluded from the study.

Samples were sent to the laboratory within two hours after collection in sterile Eppendorf tubes containing $0.5 \mathrm{ml}$ thioglicolate broth to avoid dessication and to maintain bacterial viability.

In order to isolate $H$. pylori, biopsies were seeded onto blood agar plates supplemented with $7 \%$ sheep blood, $1 \%$ yeast extract and the selective supplement DENT (Oxoid Ltd, Basingstoke, Hampshire, England). Plates were incubated at $37^{\circ} \mathrm{C}$ under microaerobic conditions $\left(6 \% \mathrm{O}_{2}, 10 \% \mathrm{CO}_{2}\right.$ y $84 \%$ $\mathrm{N}_{2}$ ) up to five days. Isolated H. pylori strains were identified using universally accepted phenotypic tests: typical morphology on Gram-stained smears and positive urease, oxidase and catalase tests $(5,16,27)$.

Quantitative susceptibility was determined in 88 strains, using the E-test ${ }^{\circledR}$ method $(5,18)$. In brief: several colonies of each strain, obtained from a fresh culture on a blood agar plate, were suspended in $5 \mathrm{ml}$ of Mueller-Hinton broth to achieve turbidity equal to the 3 Mac Farland standard. The suspensions were inoculated with sterile swabs onto $150 \mathrm{~mm}$ diameter Mueller-Hinton 7\% sheep blood agar plates and the agar surfaces were allowed to dry.Three E-test strips were applied to each plate. Plates were incubated at $37^{\circ} \mathrm{C}$ up to five days under microaerobic conditions. Inhibitory concentrations were read at the point where the elliptical zone of inhibition intersected the E-test strip. Quality control was performed using H. pylori ATCC 43504.

The antimicrobials tested were amoxicillin, ciprofloxacin, clarithromycin, gentamicin, metronidazole. The breakpoints used to define the resistance were as follows: amoxicillin ( $>2$ 
$\mu \mathrm{g} / \mathrm{ml}$ ), ciprofloxacin (>4 $\mu \mathrm{g} / \mathrm{ml})$, clarithromycin ( $2 \mu \mathrm{g} / \mathrm{ml})$, metronidazole $(>8 \mu \mathrm{g} / \mathrm{ml})$ and tetracycline $(4 \mu \mathrm{g} / \mathrm{ml})(5,18$, 27).

\section{RESULTS}

Two hundred and forty biopsy simples were analyzed. Ninety nine $(41.3 \%)$ were positive for $H$. pylori. Isolation frequencies were higher among females (42\%) than males (40.2\%). However, this difference was not statistically significant $(\mathrm{p}>0.5)$. The highest isolation frequencies were obtained in patients from 21-30 years old (55\%) and 41-50 $(52.6 \%)$ years old (Table 1) and in patients with secondary (43.9\%) and university (46.2\%) educational levels (data not shown).

Among the 88 strains studied, 19 (21.6\%) showed simultaneous resistance to more than one antimicrobial drug. MICs for metronidazole varied from $<0.016$ to $>256 \mu \mathrm{g} / \mathrm{ml}$ with $12.5 \%$ of resistance. This antimicrobial drug showed the lowest activity (Table 2).

No resistance was found for tetracycline whose CIMs ranged from $<0.016$ to $0.75 \mu \mathrm{g} / \mathrm{ml}$ (Table 2). CIMs ranges for the other four drugs were: < 0.0012 to $>32 \mu \mathrm{g} /$ for ciprofloxacin, $<0.016$ to $64 \mu \mathrm{g} / \mathrm{ml}$ for clarithromycin, $<0.016$ to $>256 \mu \mathrm{g} / \mathrm{ml}$ for amoxicillin and $<0.016$ to $>256$ for metronidazole.

The most frequently resistance patterns found were: $i$. resistance to only one antimicrobial drug: amoxicillin - 1 strain $(5.3 \%)$, ciprofloxacin - 5 strains $(26.3 \%)$, clarithromycin - 2 strains $(10.5 \%)$, metronidazole - 5 strains (26.3\%); ii. simultaneous resistance to two antimicrobials: metronidazole+clarithromycin - 5 strains (26.3\%); iii. simultaneous resistance to three antimicrobials: metronidazole+amoxicillin+clarithromycin - 1 strain $(5.3 \%)$ (Table 3).

Table 1. Helicobacter pylori isolation frequency related to age and sex.

\begin{tabular}{|c|c|c|c|c|}
\hline \multirow{2}{*}{$\begin{array}{c}\text { AGE RANGES } \\
\text { (YEARS) }\end{array}$} & \multirow{2}{*}{$\begin{array}{l}\text { MALE } \\
\text { No/n }\end{array}$} & \multirow{2}{*}{$\begin{array}{l}\text { FEMALE } \\
\mathbf{N} / \mathbf{n}\end{array}$} & \multicolumn{2}{|c|}{ TOTAL OF POSITIVE CULTURES } \\
\hline & & & $\mathbf{N} / \mathbf{n}$ & $\%$ \\
\hline $11-20$ & $2 / 4$ & $2 / 5$ & $4 / 9$ & 44.4 \\
\hline $21-30$ & $6 / 10$ & $5 / 10$ & $11 / 20$ & 55 \\
\hline $31-40$ & $5 / 15$ & $7 / 15$ & $12 / 30$ & 40 \\
\hline $41-50$ & $9 / 18$ & $12 / 20$ & $20 / 38$ & 52.6 \\
\hline $51-60$ & $6 / 14$ & $15 / 40$ & $21 / 54$ & 38.9 \\
\hline $61-70$ & $7 / 18$ & $8 / 22$ & $15 / 42$ & 35.7 \\
\hline $71-80$ & $5 / 20$ & $8 / 18$ & $14 / 37$ & 37.8 \\
\hline $81-90$ & $1 / 3$ & $1 / 8$ & $2 / 10$ & 20 \\
\hline TOTAL & $41 / 102$ & $58 / 138$ & $99 / 240$ & 41.3 \\
\hline
\end{tabular}

$\mathrm{N}^{\circ}=$ number of positive cultures

$\mathrm{n}=$ numbers of patients studied

Table 2. MICs ranges, $\mathrm{MIC}_{50}, \mathrm{MIC}_{90}$ and resistance percentages in $88 \mathrm{H}$. pylori strains to five antimicrobial drugs.

\begin{tabular}{lcccc}
\hline $\begin{array}{l}\text { ANTIMICROBIAL } \\
\text { DRUGS }\end{array}$ & $\begin{array}{c}\text { MICs RANGES } \\
(\boldsymbol{\mu c g} / \mathbf{m l})\end{array}$ & $\mathbf{M I C}_{\mathbf{5 0}}$ & $\mathbf{M I C}_{\mathbf{9 0}}$ & $\begin{array}{c}\text { RESISTANT } \\
\text { STRAINS N } / \%\end{array}$ \\
\hline Metronidazole & $<0.016->256$ & 0.125 & 1.5 & $11 / 12.5$ \\
Ciprofloxacin & $0.0012->32$ & 0.064 & 0.75 & $5 / 5.7$ \\
Clarithromycin & $<0.016-64$ & $<0.016$ & 0.19 & $8 / 9.1$ \\
Amoxicillin & $<0.016->256$ & 0.016 & 0.125 & $2 / 2.3$ \\
Tetracycline & $<0.016-0.75$ & 0.047 & 0.25 & $0 / 0$ \\
\hline
\end{tabular}


Table 3. Resistance profiles of $19 \mathrm{H}$. pylori strains.

\begin{tabular}{ll}
\hline RESISTANCE PROFILES & N\%\% \\
\hline Amoxicillin & $1 / 5.3$ \\
Clarithromycin & $2 / 10.5$ \\
Ciprofloxacin & $5 / 26.3$ \\
Metronidazole & $5 / 26.3$ \\
Metronidazole+Clarithromycin & $5 / 26.3$ \\
Amoxicillin+Clarithromycin+Metronidazole & $1 / 5.3$ \\
\hline
\end{tabular}

\section{DISCUSSION}

Being antimicrobial resistance the main reason for the treatment failure, it is necessary to identify the resistance patterns of the bacterial agents of infection. The information collected will promote a more rational and accurate use of antibiotics. In this study, we have assessed the isolation frequency of $H$. pylori in Southern Chile from patients with symptomatology compatible with gastritis or gastric ulcer and the resistance/susceptibility profiles of the isolated strains to six antimicrobial drugs, including those used in the eradication treatments.

Ninety nine out of 240 patients included in the study (41.3\%) showed positive culture for H. pylori (Table 1). In developing countries, the prevalence of people carrying $H$. pylori could reach $90 \%$, whereas in industrialized countries the infection rates reach $20-30 \%$. This difference is attributed to impaired environmental hygienic conditions frequently observed in developing countries, thus determining frequent exposure to $H$. pylori $(11,12,19,21,24)$. Previous studies in Chile, reported isolation frequencies ranging from 60 to $70 \%$ in adults (28). In this study, however, we found a lower isolation frequency (41.3\%). The differences observed among Chilean studies could be due to the use of different diagnostic methods (culture of biopsies, anti H. pylori antibodies detection, urease test and direct microscopic examination of the biopsy samples) $(3,6,7,11,12,14,21)$.

The H. pylori isolation was slightly more frequent among females (42\%) than males (40.2\%). With regard to age, the highest prevalence $(55 \%)$ was found in patients between 21 to 30 years old. This finding agrees with a report from Cortés et al. in Honduras (3) but not with that of Gonzalez-Carbajal et al. in Cuba (11). The latter reported prevalence rates near to 95\% among patients between 41 to 60 years old.

Patients with higher educational levels showed higher isolation rates (secondary educational level $43.9 \%$ and university educational level $46.2 \%$ ), probably because they are more likely to visit a doctor and be tested. These findings are in agreement with other reports from Chile and other Latin American countries (11, 15, 22, 23).

Nineteen $(21.6 \%)$ strains showed resistance to at least one antimicrobial drug. As shown in Table 2, two strains $(2,3 \%)$ were resistant to amoxicillin. Global H. pylori resistance to amoxicillin is low $(17,28)$. Fariña et al (5) reported a $2.2 \%$ resistance in Paraguay, whereas González et al in Chile (10), López-Brea et al in Spain (13), Urrestarazu et al in Venezuela (27) and Wolle et al (31) in Germany did not find H. pylori strains resistant to amoxicillin. The broad use of this antibiotic to treat different infectious conditions could have contributed to the development of resistant strains.

Eight strains were resistant to clarithromycin (9.1\%). $H$. pylori resistance to this antibiotic is usually low and variable, geographically. However, increasing of clarithromycin resistance could be expected due to its use in the treatment of extra-digestive infections $(5,17,29)$. Our results are lower than those reported by Vallejos et al (29) in the Metropolitan Region of Chile (20\%) and by De Francesco et al (4) in Italy (24.2\%). However, many studies reported lower resistance frequencies, ranging between 2 and $7 \%(5,10,13,27,31)$ thus, corroborating the geographic variation of $H$. pylori resistance to clarithromycin (32).

Metronidazole showed the lowest activity with 11 (12.5\%) 
resistant strains. Several studies have demonstrated the existence of a high percentage of resistant strains, probably due to use of this drug in the treatment of gynecologic, dental and gastrointestinal infections $(1,17,31)$. Their use in gynecological infections could explain the higher resistance observed in strains isolated from females. On the other hand, their use in treating giardiasis and amebiasis could explain the higher resistance in developing countries (28). López-Brea et al in Spain reported $19.9 \%$ resistance (13) while other authors, in Chile and other countries, reported resistance percentages from 26.2 to $67 \%(5,25,27,29,31)$. This corroborates the need to establish the resistance profiles of the local $H$. pylori strains.

None of the strains were resistant to tetracycline. Similar results were obtained by López-Brea et al (13) in Spain and Wolle et al (31) in Germany, while Pajares et al (17) reported that $H$. pylori resistance to tetracycline ranges from 0 to $1 \%$. However, other authors $(27,29)$ reported resistance percentages varying from 7 to $26.8 \%$ thus, indicating that the resistance levels are influenced by the local use of antibiotics.

This antibiotic has been used together with furazolidone to treat $H$. pylori infection in Brazil, China and Peru, due to their low cost and to the resistance to metronidazole and macrolides found in those countries (2).

Five strains $(5.7 \%)$ were resistant to ciprofloxacin. This finding agrees with data reported by Toro et al (26) in Spain (7.9\%) and Glocker et al (9) in Germany (9.5\%). The highest resistance frequency to ciprofloxacin $(21 \%)$ has been reported in Portugal (17).

Simultaneous resistance was observed in six strains. Five were simultaneously resistant to metronidazole and clarithromycin and one to amoxicillin, clarithromycin and metronidazole. Since these antimicrobials are the most frequently recommended in $H$. pylori eradication treatments, these findings highlight an urgent need to establish a resistance surveillance system in order to prevent treatment failures and the spread of resistant strains. In addition, it is important to establish whether these resistant strains represent sporadic cases or correspond to an usual resistance behavior in a given geographic region.

\section{ACKNOWLEDGMENTS}

Thanks are due to Dr. Eleonora Altman (Institute for Biological Sciences, National Research Council of Canada, Ottawa, Canada) for her advices and critical review.

This work received financial support from Grant DIDUACh S-2006-25

\section{REFERENCES}

1. Alarcón, T.; Domingo, D.; López-Brea, M. (1998). Discrepancies between $\mathrm{E}$ test and agar dilution methods for testing metronidazole susceptibility of Helicobacter pylori. J. Clin. Microbiol. 36, 1165 - 1166.

2. Araujo, R.; Pinto, J.L.; Ramírez, D.; Cok, J.; Bussalleu, A.J. (2005). Nuevo esquema ultracorto para erradicar la infección por Helicobacter pylori utilizando tetraciclina, furazolidona y subcitrato de bismuto coloidal en pacientes dispépticos con o sin úlcera péptica en el Hospital Nacional Cayetano Heredia. Rev. Gastroenterol. Peru. 25 (1), 23 - 41.

3. Cortés-Padilla, D.E.; Torres-Herrera, G. (1997). Prevalencia de Helicobacter pylori en enfermedad ácido-péptica y gastritis crónica, y respuesta terapéutica. Rev. Med. Hondur. 65 (4), 101 - 106.

4. De Francesco, V.; Margiotta, M.; Zullo, A.; Hassan, C.; Della Valle, N.; Burattini, O.; D’Angelo, R; Stoppino, G.; Cea, U.; Giorgio, F.; Monno, R.; Morini, S.; Panella, C.; Ierardi, E. (2006) Claritromycin resistance and Helicobacter pylori genotypes in Italy. J. Microbiol. 44 (6), 660 664.

5. Fariña, N.; Kasamatsu, E.; Samudio, M.; Morán, M.; Sanabria, R.; Laspina, F. (2007). Susceptibilidad a antibióticos de cepas paraguayas de Helicobacter pylori aisladas de pacientes con enfermedad gastroduodenal. Rev. Méd. Chile. 135, 1009 - 1014.

6. Fernández, H.; Ibarra, H.; Toledo, C. (1989). Aislamiento de Campylobacter pylori en biopsias gástricas en habitantes del sur de Chile. Rev. Méd. Chile. 117, 1180 - 1181.

7. Figueroa, G.; Troncoso, M.; Portell, D.; Toledo, M.; Acuña, R.; Arellano, L. (1993). Prevalence of immunoglobulin G antibodies to Helicobacter pylori in Chilean individuals. Eur. J. Clin. Microbiol. Infect. Dis. 12, 795 - 797.

8. Fischbach, L.; Evans, E.L. (2007). Meta-analysis: the effect of antibiotic resistance status on the efficacy of triple and quadruple first-line 
therapies for Helicobacter pylori. Aliment. Pharmacol. Ther. 26 (3), 343 -357 .

9. Glocker, E.; Stueger, H.P.; Kist, M. (2007). Quinolone Resistance in Helicobacter pylori Isolates in Germany. Antimicrob. Ag. Chemother. 51 (1), 346 - 349 .

10. Gonzalez, C.; Garcia, A.; Daroch, F.; Kawaguchi, F.; Solar, H.; Rivera, N.; Vega, E. (2001). Susceptibilidad in vitro de cepas de Helicobacter pylori: aislamiento de cepas resistentes a claritromicina. Rev. Med. Chile. 129 (6), 643 - 646.

11. Gonzalez-Carbajal, M.; Rojas, F.; Grá, B.; Ávalos, R. (2004). Prevalencia de la infección por Helicobacter pylori en pacientes dispépticos. Rev. Panam. Infectol. 6 (4), 8 - 14.

12. Harris, P.; Serrano, C.; Venegas, A. (2006). Vacunas en desarrollo: Helicobacter pylori. Rev. Chil. Infect. 23 (3), 249 - 256.

13. López-Brea, M.; Domingo, D.; Sanchez, I.; Alarcon, T. (1997) Evolution of resistance to metronidazole and clarithromycin in Helicobacter pylori clinical isolates from Spain. J. Antimicrob. Chemother. 40, 279 - 281.

14. Macenlle, R.; Gayoso, P.; Sueiro, R.A.; Fernández, J. (2006). Prevalencia de la infección por Helicobacter pylori en la población general adulta de la provincia de Ourense. Rev Esp Enferm Dig 98 (4), 241-248.

15. Moayyedi, P.; Axon, A.; Feltbower, R.; Duffett, S.; Crocombe, W.; Braunholtz, D.; Richards, G.; Dowell, A.C.; Forman, D. (2002). Relation of adult lifestyle and socioeconomic factors to the prevalence of Helicobacter pylori infection. Int. J. Epidemiol. 31 (3), 624-631.

16. Engberg, J.; On, S.L.; Harrington, C.S.; Gerner-Smidt, P. (2000). Prevalence of Campylobacter, Arcobacter, Helicobacter, and Sutterella spp. in human fecal samples as estimated by a reevaluation of isolation methods for campylobacters. J. Clin. Microbiol. 38 (1), 286-291.

17. 17.Pajares, J.M.; Pajares-Villarroya, R.; Gisbert, J.P. (2007). Helicobacter pylori infection: antibiotic resistance. Rev. Esp. Enferm. Dig. 99 (2), 63-70.

18. Piccolomini, R.; Di Bonaventura, G.; Catamo, G.; Carbone, F.; Neri, M. (1997). Comparative evaluation of the $\mathrm{E}$ test, agar dilution, and broth microdilution for testing susceptibilities of Helicobacter pylori strains to 20 antimicrobials agents. J. Clin. Microb. 35 (7), 1842-1846.

19. Pounder, R.E.; Ng, D. (1995). The prevalence of Helicobacter pylori infections in different countries. Aliment. Pharmacol. Ther. 9 (s2), 33-39.

20. Riquelm,e A.; Soza, A.; Pedreros, C.; Bustamante, A.; Valenzuela, F.; Otarola, F.; Abbott, E.; Arellano, M.; Medina, B.; Pattillo, A.; Greig, D.; Arrese, M.; Rollan, A. (2007). Optimal length of triple therapy for $H$ pylori eradication in a population with high prevalence of infection in
Chile. World J. Gastroenterol. 13 (21), 2967-2972.

21. Rivas-Traverso, F.; Hernandez, F. (2000) Helicobacter pylori: Factores de virulencia, patología y diagnóstico. Rev. Biomed. 11 (3), 187-205.

22. Santos, .S.; Boccio, J.; Santos. A.S.; Valle, N.C.J.; Halal C.S.; Bachilli, M.C.; Lopes, R.D. (2005). Prevalence of Helicobacter pylori infection and associated factors among adults in Southern Brazil: a populationbased cross-sectional study. BMC Public Health. 5, 118-127.

23. Sarmiento, F.; Chávez, E.; Pizarro, B.; Kakarieka, E.; Vial, M.T.; Gotteland, M. (1997). Infección por Helicobacter pylori y daño gástrico en niños de nivel socioeconómico bajo. Rev. Chil. Pediatr. 68 (6), 251255 .

24. Slater, E.; Owen, R.J.; Williams, M.; Pounder, R.E. (1999). Conservation of the cag pathogenicity island of Helicobacter pylori: associations with vacuolating cytotxin allele and IS605 diversity. Gastroenterology. 117, 1308-1315.

25. Solca, N.M.; Bernasconi, M.V.; Piffaretti, J.C. (2000). Mechanism of metronidazole resistance in Helicobacter pylori: comparison of the $r d x A$ gene sequences in 30 strains. Antimicrob. Ag. Chemother. 44 (8), 22072210.

26. Toro, C.; Garcia-Samaniego, J.; Carbó, J.; Iñiguez, A.; Alarcón, T.; Lopez-Brea, M.; Baquero, M. (2001). Prevalencia de la resistencia primaria de Helicobacter pylori a ocho antimicrobianos en un hospital de Madrid. Rev. Esp. Quimioter. 14, 172-176.

27. Urrestarazu, M.I.; Serrano, N.; Piñero, R.; Cavazza, M.E. (2003). Susceptibilidad de Helicobacter pylori a los antimicrobianos. Rev. Soc. Ven. Microbiol. 23 (1), 14-15.

28. Vallejos, C.; Cerda, O.; Valenzuela, M.; Toledo, H. (2003). Resistencia antimicrobiana en Helicobacter pylori: aspectos clínicos y moleculares. Rev. Méd. Chile. 131 (11), 1313-1320.

29. Vallejos, C.; Garrido, L.; Cáceres, D.; Madrid, A.M.; Defilippi, C.; Toledo, H. (2007). Prevalencia de la resistencia a metronidazole, clarithromycin y tetraciclina en Helicobacter pylori aislado de pacientes de la región metropolitana. Rev. Med. Chile. 135 (3), 287-293.

30. Warren, J.R.; Marshall, B.J. (1983). Unidentified curved bacilli on gastric epithelium in active chronic gastritis. Lancet. 1, 1273-1275.

31. Wolle, K.; Leodolter, A.; Malfertheiner, P.; König, W. (2002). Antibiotic susceptibility of Helicobacter pylori in Germany: stable primary resistance from 1995 to 2000. J. Med. Microbiol. 51, 705-709.

32. Xia, H.X.; Fan, X.G.; Talley, N.J. (1999). Clarithromycin resistance in Helicobacter pylori and its clinical relevance. World J. Gastroenterol. 5 (3), 263-266. 